\title{
ANALISIS STRATEGI KOMUNIKASI PEMERINTAH KOTA BALIKPAPAN DALAM MERAIH ADIPURA KENCANA 2017
}

\author{
Aris Dwi Andrianto \\ Komunikasi Korporat, Magister Ilmu Komunikasi, London School of Public Relation Jakarta \\ Sudirman Park Campus B Post Graduate LSPR, Karet, DKI Jakarta \\ E-mail : adandrianto@yahoo.co.id
}

\begin{abstract}
ABSTRAK
Kementerian Lingkungan Hidup dan Kehutanan Republik Indonesia menyelenggarakan program Adipura setiap tahunnya sebagai upaya untuk mewujudkan wilayah Indonesia yang berwawasan lingkungan menuju pembangunan yang berkelanjutan. Pemerintah Kota Balikpapan sebagai satu-satunya kota di luar Pulau Jawa kembali meraih penghargaan Adipura Kencana 2017 setelah berhasilmempertahankan penghargaan yang sama sejak tahun 2013. Prestasi ini menambah deretan penghargaan Kota Balikpapan yang pernah juga menyabet gelar sebagai kota terbersih se-ASEAN tahun 2014 dan The Most Lovable Sustainable City 2015 ditengah menggeliatnya pembangunan Kota Balikpapan. Tujuan dari penelitian ini adalah untuk mengetahui dan memahami strategi komunikasi Pemerintah Kota Balikpapan dalam meraih penghargaan Adipura Kencana 2017 dalam meyakinkan, merubah, dan meraih kepercayaan publik Kota Balikpapan. Teori yang digunakan dalam memahami fenomena sosial tersebut adalah teori strategi komunikasi dan teori Propaganda dengan menggunakan pendekatan kualitatif dan mewawancarai narasumber dari Dinas Lingkungan Hidup Pemerintah Kota Balikpapan.Hasil dari penelitian ini menunjukkan bahwa Pemerintah Kota Balikpapan telah melakukan strategi komunikasi dan persuasi massa secara proaktif yang dimulai sejak lama dan berjalan secara berkesinambungan, dalam lingkup komunikasi internal dan eksternal, baik formal maupun informal, melalui media-media yang tersedia, termasuk media massa dan internet, untuk mendapatkan dukungan publik Kota Balikpapan dalam program Adipura.
\end{abstract}

Kata Kunci: Adipura, strategi komunikasi, Pemerintah Kota Balikpapan, Persuasi Massa

\section{PENDAHULUAN}

Pemerintah Kota Balikpapan kembali berhasil meraih penghargaan Adipura Kencana 2017 setelah mempertahankan penghargaan yang sama sejak tahun 2013 (Pemkot Balikpapan, 2018). Prestasi yang hanya bisa diraih oleh segelintir kota di Indonesia. Bahkan prestasi Kota Balikpapan yang terletak di Propinsi Kalimantan Timur pada tahun 2017 lalu adalah pencapaian yang luar biasa karena merupakan satusatunya kota di luar Jawa yang meraih Adipura Kencana tahun 2017. Tercatat juga hanya ada dua (2) kota di Indonesia yang pada gelaran Adipura 2017 yang meraih penghargaan Adipura Kencana secara berturut-turut, yaitu Kota Balikpapan dan Kota Surabaya (Diskominfo Balikpapan, 2017).

Program Adipura, sebagaimana dikutip dari Peraturan Menteri Lingkungan Hidup dan Kehutanan (LHK) Republik Indonesia P.53/Menlhk/Setjen/Kum.1/6/2016 tentang Pedoman Pelaksanaan Program Adipura, adalah program kerja Kementerian Lingkungan Hidup dan Kehutanan (KLHK) yang berlingkup nasional untuk mewujudkan wilayah yang berwawasan lingkungan menuju pembangunan yang berkelanjutan (KLHK, 2016) sesuai dengan amanat Undang-Undang Dasar (UUD) 1945 dan peraturan hukum turunannya.
Program Adipura dilaksanakan pada kota/kabupaten di Indonesia sesuai dengan kategori fungsional kota yaitu kategori kota kecil dengan jumlah penduduk 20.000 jiwa hingga 100.000 jiwa, kota sedang dengan jumlah penduduk 100.001 hingga 500.000 jiwa, kota besar dengan jumlah penduduk 500.001 hingga 1 juta jiwa, dan kategori terakhir kota metropolitan dengan jumlah penduduk lebih besar dari 1 juta jiwa (KLH, 2016).

Dengan jumlah penduduk sebesar 706.414 jiwa (dikutip dari dari laman www.balikpapan.go.id, data penduduk tahun 2015), Kota Balikpapan termasuk dalam kategori kota besar dan berhak bersaing dengan kotakota besar lainnya di seluruh Indonesia untuk memperebutkan Piala Adipura katergori Kota Besar.

Untuk meraih Adipura, Pemerintah Kota Balikpapan harus mampu mengajak partisipasi aktif masyarakat dan dunia usaha untuk turut serta dalam mensukseskan program Adipura. Dalam hal ini, Pemerintah Kota Balikpapan dituntut untuk memiliki strategi komunikasi program Adipura untuk disampaikan dan dilaksanakan oleh seluruh pemangku kepentingan, karena komunikasi organisasi merupakan infrastruktur profesional untuk mengembangkan dan mendistribusikan informasi melalui cara yang dapat dipercaya dan tidak lekang waktu sebagaimana Prayudi pada Rochmah (2012). Sedangkan 
West dan Turner (2010) menyatakan bahwa komunikasi organisasi mencakup komunikasi yang terjadi di dalam dan di antara lingkungan kerja. Juga meliputi komunikasi interpersonal (antara atasan dan bawahan), kesempatan berbicara di depan publik, kelompok kecil, dan komunikasi dengan menggunakan media (West \& Turner, 2010).

Dengan mempertimbangkan informasi di atas, peneliti akan meneliti strategi komunikasi Pemerintah Kota Balikpapan dalam meraih penghargaan Adipura Kencana 2017. Beberapa pertimbangan yang peneliti gunakan adalah bahwa Balikpapan merupakan satusatunya Kota di luar Jawa yang mendapatkan anugerah Adipura Kencana tahun 2017,sedangkan untuk memperoleh Adipura Kencana sendiri memerlukan persyaratan yang tidak mudah dimana salah satu persyaratannya adalah kota tersebut harus mampu meraih Adipura minimal tiga kali berturut-turut. Keberhasilan ini merupakan buah kerja keras Pemerintah Kota Balikpapan dalam mengkomunikasikan program Adipura kepada seluruh pemangku kepentingan di Kota Balikpapan dan dalam mendorong partisipasi aktif pemangku kepentingan tersebut untuk turut serta berkontribusi dalam program pembangunan Kota Balikpapan khususnya dalam menjaga lingkungan hidup dan kebersihan Kota Balikpapan.

Ditambah lagi persyaratan penilaian program Adipura 2017 dinyatakan lebih ketat apabila dibandingkan dengan tahun-tahun sebelumnya (DLH Samarinda, 2017), sehingga kota-kota yang berhasil memperoleh Adipura dan Adipura Kencana pada tahun 2017 adalah kota-kota yang memiliki kelebihan dibandingkan dengan kota-kota lain di seluruh Indonesia. Terlebih juga pada penelitian-penelitian sebelumnya yang dilakukan oleh Samsuriyadi (2017) yang meneliti strategi Pemerintah Kota Bintan (kategori kota kecil) dalam meraih Adipura pertamanya dari sisi keilmuan Ilmu Pemerintahan dan penelitian Septiana (2016) yang meneliti Adipura Kota Pekanbaru dari keilmuan Ilmu Administrasi Negara, keduanya tidak melihat dari sisi keilmuan Ilmu Komunikasi pada kasus yang diteliti. Padahal, komunikasi merupakan komponen dasar dan penting yang pasti dilakukan oleh setiap organisasi dan karenanya menjadi penting untuk mengetahui strategi komunikasi suatu organisasi dalam meraih prestasi tingkat nasional dan bahkan internasional.

\section{RUANG LINGKUP}

Di dalam penelitian ini ruang lingkup permasalahan yang diteliti meliputi:

1. Rumusan masalah yang akan diteliti pada penelitian ini adalah Bagaimana pelaksanaan Strategi Komunikasi Pemerintah Kota Balikpapan dalam Meraih Adipura Kencana 2017

2. Membatasi pada pelaksanaan Strategi Komunikasi Pemerintah Kota Balikpapan dan tidak meneliti proses perencanaan Strategi Komunikasi tersebut.
3. Dan diharapkan melalui penelitian ini dapat diketahui dan dipahami Strategi Komunikasi Pemerintah Kota Balikpapan dalam Meraih Adipura Kencana 2017.

\section{BAHAN DAN METODE}

Untuk membantu peneliti dalam menjawab permasalahan pada penelitian ini, peneliti menggunakan pendekatan studi kasus kualitatif interpretif dengan menggunakan teori Strategi Komunikasi dan teori Propaganda.

\subsection{Propaganda Sebagai Persuasi Massa}

Dalam memahami lebih baik fenomena suatu organisasi yang berusaha meyakinkan publiknya untuk berpartisipasi dan mengikuti keinginan organisasi tersebut, teori yang dapat membantu menjawab fenomena tersebut adalah teori Propaganda. Littlejohn dan Foss (2009) mendefinisikan propaganda sebagai bagian dari komunikasi yang melibatkan keinginan untuk mendukung atau merubah kepercayaan dan perilaku orang. Lebih lanjut, Littlejohn dan Foss (2009) menjelaskan bahwa propaganda merupakan bagian dari persuasi, yang juga didalamnya melibatkan aktivitas menciptakan, menguatkan, atau merubah kepercayaan, tindakan, dan perilaku. Dalam bagian lain, Littlejohn dan Foss (2009) menyatakan bahwa persuasi merupakan bagian dari komunikasi yang melibatkan niatan untuk mendukung atau merubah kepercayaan dan perilaku orang. Propaganda dalam bentuk persuasi ini biasa dijadikan sebagai cara-cara pemerintah, iklan, agama, pendidikan dan agenda-agenda organisasi lainnya (Littlejohn \& Foss, 2009).

\subsection{Teori Strategi Komunikasi}

Strategi, menurut Robbins dan Barnwell pada Harrison (2011), merupakan penentuan tujuan jangka panjang, diterjemahkan ke dalam tindakan-tindakan dan pengalokasian sumber daya untuk mencapai tujuan tersebut. Menurut Smith (2013), strategi adalah adalah hati dari perencanaan public relations "strategy is the heart of planning for public relations..." dan karena public relations bermula dari publik (Smith, 2013), maka pada umumnya public relations membangun rencana strategis komunikasi dari pemahaman yang baik terhadap hubungan yang sedang berjalan antara organisasi dengan publiknya (Smith, 2013).

Strategi memiliki dua fokus utama, yaitu apa yang dilakukan (action) oleh organisasi baik proaktif maupun reaktif dan isi (content) dan penampilan dari pesan (message) yang disampaikan (Smith, 2013). Ruslan pada Rochmah (2012) mendefinisikan strategi sebagai "perencanaan dan manajemen untuk mencapai tujuan tertentu dalam praktik operasionalnya" dan dalam kontek komunikasi, maka strategi komunikasi dapat diartikan sebagai perencanaan dan manajemen komunikasi untuk mencapai tujuan komunikasi suatu organisasi.

Rochmah (2012) menambahkan bahwa strategi komunikasi merupakan kegiatan komunikasi yang 
sifatnya informasional maupun persuasif untuk membangun pemahaman dan dukungan suatu ide, gagasan atau kasus, produk maupun jasa yang direncanakan dan dilakukan oleh suatu organisasi baik yang berorientasi laba maupun nirlaba, dengan tujuan, rencana dan berbagai alternatif berdasarkan riset dan evaluasi.

Dalam menjalankan strategi komunikasinya, sebuah organisasi dapat melakukannya dengan dua pendekatan, yaitu strategi yang bersifat proaktif dan strategi yang reaktif (Smith, 2013). Pada pendekatan yang proaktif ini, organisasi dapat menjalankan program komunikasinya sesuai dengan kondisi dan rencana dari organisasi tersebut, dan terdiri atas dua kegiatan utama yaitu rincian tindakan dan yang menyangkut komunikasinya. Pendekatan ini dapat menjadi strategi yang paling efektif karena dapat dilakukan sesuai dengan rencana/program kerja dari organisasi tersebut. Aktivitasaktivitas/tindakan yang termasuk dalam kategori strategi proaktif ini diantaranya adalah melalui usaha peningkatan prestasi organisasi, kegiatan yang berfokus pada peningkatan partisipasi peserta/target sasaran, menjalin kerja sama koalisi/partnership, sponsorship, dan berbagai kegiatan berbasis pada tindakan aktif lainnya. Sedangkan kunci dari strategi komunikasi yang proaktif ini terletak pada publikasi/publisitas, informasi yang bernilai berita, dan pembangunan proses komunikasi yang transparan (Smith, 2013), yang akan kita bahas pada ulasan di bawah ini.

1. Publikasi/Publisitas

Smith (2013) mengutarakan bahwa inti dari publikasi/publisitas adalah adanya third party endorsement yaitu dukungan yang diberikan oleh pihak ketiga yang menyampaikan pesan organisasi, menyuarakan kredibilitas dari organisasi tersebut yang biasanya diulas oleh media seperti reporter/editor pada tajuk media terkait. Hal ini dinilai menguntungkan bagi organisasi karena orang/pendengar merasa bahwa berita yang mereka peroleh melalui media tv, koran, radio lebih dapat dipercaya daripada media yang dimiliki oleh organisasi tersebut seperti iklan, website, brosur dan lain-lain (Smith, 2013), sehingga dengan sendirinya organisasi menjadi dikenal baik/didukung oleh pemangku kepentingannya.

2. Informasi yang bernilai berita

Penyampaian informasi yang memiliki nilai berita pada media massa adalah keharusan bagi organisasi yang hendak mendapatkan perhatian massa selagi menyampaikan isi/pesan dari organisasi tersebut (Smith, 2013). Bagi suatu organisasi, ulasan berita adalah salah satu strategi komunikasi proaktif yang paling besar dampaknya karena sesuatu yang bernilai berita biasanya akan menjadi perhatian dari media massa untuk meliputnya, dan pada akhirnya, dapat menjangkau publik dari organisasi tersebut.

3. Proses komunikasi yang transparan
Smith (2013) mendefinisikan komunikasi yang transparan sebagai penggambaran atas adanya keterbukaan dan dapat diamatinya aktivitas suatu organisasi dapat membantu publik memahami organisasi tersebut dan sebagai timbal baliknya memberikan dukungan terhadap organisasi tersebut. Smith (2013) menambahkan bahwa ketika organisasi terlibat dalam komunikasi yang transparan, mereka menampilkan komunikasi yang mampu menunjukkan masalah, mendapatkan perhatian publik, memunculkan berbagai pilihanpilihan ide, dan jika tidak, dapat menciptakan pemahaman dan keterlibatan sebelum sebuah rencana diumumkan, terutama dalam kaitannya dengan hal-hal yang melibatkan/mempengaruhi kepentingan publik.

Pada pendekatan strategi komunikasi kedua, yaitu pada pendekatan strategi yang reaktif, organisasi bertindak/berkomunikasi sebagai reaksi atas adanya tindakan dari pihak lain (Smith, 2013). Dalam kondisi ini, organisasi perlu menyiapkan serangkaian tindakan/tujuan yang dimaksudkan untuk mendapatkan dukungan atau pengertian dari publik, mempertahankan atau mengembalikan reputasi, dan upaya membangun kembali kepercayaan dan dukungan dari publiknya (Smith, 2013). Salah satu strategi yang termasuk dalam bagian dari strategi reaktif ini adalah strategi tindakan perbaikan (rectifying behavior strategies) yang terdiri atas (Smith, 2013):

1. Investigasi

Dalam kondisi ini organisasi berjanji akan melakukan tindakan yang dianggap perlu untuk memperbaiki keadaan. Strategi ini baik digunakan untuk mengulur waktu sambil menyiapkan strategi lain yang lebih sesuai/menguntungkan bagi organisasi.

2. Tindakan Perbaikan

Strategi ini dibarengi dengan tindakan nyata untuk mengisolasi permasalahan, melakukan perbaikan dan mencegah terulangnya kejadian serupa. Strategi ini dianggap sebagai bentuk simbiosis mutualisme antara organisasi dan publiknya, dan dapat dipilih apabila organisasi berada dalam posisi mampu/harus menyelesaikan masalah, yang biasanya juga diakibatkan oleh adanya kelalaian atau ketidaksiapan organisasi.

3. Pemulihan

Strategi yang juga menampung kepentingan dari kedua belah pihak (organisasi dan publik). Bentuk dari jenis strategi ini adalah kesiapan dari organisasi untuk melakukan berbagai tindakan dalam upaya untuk mengembalikan sebagaimana kondisi semula.

4. Penyesalan

Strategi ini memberikan dampak besar yang mana melibatkan perubahan pada hati dan diiringi perubahan tindakan. Strategi ini menjadi sinyal penebusan atas segala kesalahan/kelalaian yang 
dilakukan organisasi di masa lalu dan merubahnya menjadi sosok yang baru dalam beroperasi.

Pace, Peterson, dan Burnett pada Effendy (2009) menjelaskan tentang tujuan dilakukannya strategi komunikasi adalah :

1. To secure understanding, untuk memastikan terdapatnya pemahaman dan saling pengertian di dalam komunikasi,

2. To establish acceptance, agar diperoleh penerimaan,

3. To motivate action, termotivasi untuk melakukan tindakan.

Pace dan Faules pada Rochmah (2012) menambahkan satu komponen lagi sebagai tujuan utama strategi komunikasi yaitu,

4. The goals the communicator sought to achieve, yaitu untuk menjelaskan tujuan yang hendak dicapai oleh pihak komunikator.

Dalam menjalankan strategi komunikasi, sebuah organisasi juga dituntut untuk menyiapkan taktik komunikasi yang disesuaikan dengan masing-masing kondisi, karena taktik komunikasi merupakan elemen nyata dari sebuah rencana strategis (Smith, 2013) dan juga karena taktik adalah berbagai cara atau aktivitas yang dilakukan untuk menjalankan strategi (Gregory, 2010). Salah satu cara untuk menentukan taktik dan media komunikasi adalah berdasarkan lingkup cakupannya dalam hubungannya dengan kebutuhan setiap organisasi, yaitu (Smith, 2013):

1. Komunikasi interpersonal

Melibatkan hubungan tatap muka dalam lingkup hubungan personal dan adanya interaksi didalamnya

2. Media Organisasi

Dikeluarkan atau dibuat oleh organisasi terkait, dimana kontrol atas isi, waktu, kemasan, dan distribusi diatur oleh organisasi tersebut

3. Media Berita

Adanya kesempatan bagi organisasi agar dapat menjangkau publik yang lebih luas

4. Media Iklan atau Promosi

Serupa dengan taktik no.3 di atas yang biasa dikeluarkan oleh pihak lain dengan harapan dapat menjangkau publik yang lebih luas.

Keempat taktik dan media komunikasi di atas saling melengkapi dan dapat dikombinasikan satu dengan yang lainnya untuk mendapatkan efek yang sesuai dengan tujuan dan kebutuhan organisasi (Smith, 2013).

\subsection{Metode Penelitian}

Denzin dan Lincoln (2009) menjelaskan bahwa studi kasus adalah bagian dari metode ilmiah dan studi kasus kualitatif memiliki ciri bahwa peneliti menghabiskan waktu yang cukup di lapangan, secara langsung berinteraksi dengan berbagai aktivitas dan berlangsungnya kasus yang diteliti, sambil merefleksikan dan memperbaiki makna-makna yang muncul. Denzin dan Lincoln (2009) lebih jauh menjelaskan keunggulan studi kasus terletak pada perbaikan teori (refining theory) dan kompleksitas kasus atau isu yang dibahas dapat menjadi bahan penelitian yang akan datang, sekaligus dapat menjadi bukti dari keterbatasan konsep generalisasi suatu penelitian. Selain itu studi kasus juga dapat digunakan sebagai bagian dari pendekatan keilmuan dalam ranah kebijakan publik dalam aspek perluasan pengalamannya (Denzin \& Lincoln, 2009) sesuai dimana penelitian ini yang meneliti strategiPemerintah Kota Balikpapan.

Sementara itu, sebagaimana Creswell (2016) kemukakan bahwa karakterisktik pokok penelitian kualitatif adalah:

1. Lingkungan alamiah, dimana dalam lingkungan natural, para peneliti kualitatif melakukan interaksi secara tatap muka dengan partisipan

2. Peneliti sebagai kunci utama dalam pengumpulan data, baik melalui dokumentasi, observasi, atau wawancara dengan partisipan

3. Terdapat berbagai sumber data, termasuk didalamnya dokumentasi, observasi lapangan, wawancara dan terdapat pemberian makna atas data-data tersebut

4. Analisis induktif, dari khusus ke umum

5. Pemberian makna dari partisipan

6. Rancangan yang berkembang/dinamis

7. Reflektivitas peran peneliti dalam penelitian

8. Pandangan yang menyeluruh (Creswell, 2016)

Penelitian kualitatif menekankan pada kekhususan dibandingkan dengan generalisasi, sebagaimana Greene dan Caracelli pada Creswell (2016), sebagaimana juga merupakan karakteristik dari metode penelitian studi kasus. Selain itu penelitian kualitatif juga memberikan penekanan makna realitas yang terbangun secara sosial, hubungan erat antara peneliti dengan subjek yang diteliti (Denzin \& Lincoln, 2009) yang mana peneliti terlibat dan menginterpretasikan dirinya dalam pengalaman yang berkelanjutan dan terus-menerus dengan para partisipan (Creswell, 2016).

Pengumpulan data primer pada penelitian ini diperoleh melalui wawancara semi terstruktur Frey dan Fontana pada Denzin dan Lincoln (2009), sedangkan data pendukung/sekunder diperoleh melalui studi pustaka, dokumentasi, gambar/foto, browsing. Wawancara kepada tiga narasumber dilakukan pada tanggal 10 dan 11 Juli 2018 yaitu Kepala Dinas Lingkungan Hidup, Bagian Penataan Hukum dan Peningkatan Kualitas Lingkungan Hidup, dan Bagian Kebersihan.

Data yang telah terkumpul kemudian dianalisa dengan tujuan untuk memaknai data tersebut dengan mengelompokkan atau memilah, dan menyusunnya kembali (Creswell, 2016) dan mencari pola yang penting atau temuan yang penting (Ary, Jacobs, Sorensen dan Razavieh, 2010). Peneliti memilih menggunakan model analisa data interactive model sebagaimana terlihat pada gambar 1 (Miles dan Huberman pada Miles, Huberman, \& Saldana, 2014). 


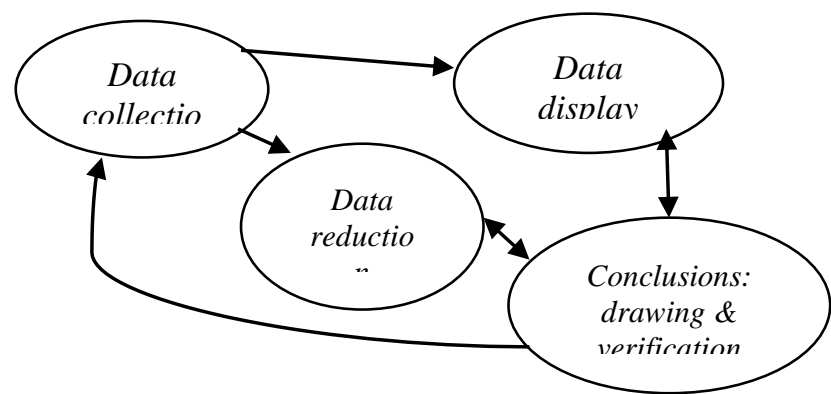

Gambar 1. Interactive Model Miles dan Huberman

Dalam menguji validitas penelitian ini, peneliti akan menggunakan metode triangulasi sumber (Denzin pada Moleong, 2010) dan disajikan dalam bentuk naratif (Miles dan Huberman pada Creswell, 2016).

\section{PEMBAHASAN}

Dalam upaya untuk meyakinkan dan memperoleh dukungan masyarakat Kota Balikpapan terkait program Adipura pada tahun 2017, tentang pentingnya menjaga kelestarian dan kondisi lingkungan hidup Kota Balikpapan, dan bahwa Adipura merupakan salah satu tolok ukur keberhasilan pembangunan, dalam mencapai visi dan misi Kota Balikpapan, dapat diketahui bahwa capaian Adipura Kencana 2017 yang lalu bukanlah hasil komunikasi instan atau tanpa perencanaan. Sebagaimana hasil wawancara dengan Kepala Dinas Lingkungan Hidup Pemerintah Kota Balikpapan Bapak Suryanto pada 11 Juli 2018, bahwa keberhasilan Kota Balikpapan dalam meraih Adipura Kencana 2017 merupakan hasil dari rangkaian proses komunikasi dan usaha dari Pemerintah Kota Balikpapan selama bertahun-tahun.

Ditambahkan oleh Bapak Suryanto, Kota Balikpapan memiliki keunggulan-keunggulan sehingga layak menjadi penerima penghargaan Adipura Kencana 2017, yaitu, Pertama dan Kedua, keunggulan fisik dan tata ruang yang mumpuni. Konsep pembangunan tata kota secara fisik yaitu konsep 52-48 dijalankan dengan baik oleh Pemerintah Kota Balikpapan, dimana alokasi 52\% untuk hutan lindung, sedangkan $48 \%$ dialokasikan untuk budidaya. Keunggulan fisik lainnya adalah pelarangan kegiatan pertambangan batu bara di wilayah Kota Balikpapan. Hal ini juga senada dengan informasi yang tersedia dalam laman website Kota Balikpapan, dimana tujuan dari pengaturan alokasi ini adalah sebagai komitmen Kota Balikpapan dalam menghindari kerusakan lingkungan (Pemkot Balikpapan, 2018) sebagaimana yang terjadi pada kota-kota lainnya di Indonesia.

Keunggulan Ketiga adalah konsistensi dan komitmen kepemimpinan terkait lingkungan hidup. Konsistensi yang dimaksud adalah konsistensi estafet kepemimpinan pemimpin Kota Balikpapan dalam memberikan perhatian terhadap lingkungan hidup wilayah sejak era Bapak Kol. CZI. TNI. AS. Syarifudin Yoes yang menjabat sebagai
Walikota Balikpapan pada tahun 1981 hingga 1989 (Pemkot Balikpapan, 2018) dengan slogan K4 (Kebersihan, Keindahan, dan Ketertiban Kota), yang juga secara konsisten dilanjutkan oleh pemimpinpemimpin Kota Balikpapan sesudahnya, yaitu $H$. Herman Okol (sebagai Plt. Walikota) dari tahun 1989 hingga tahun 1991 dan dilanjutkan oleh Kol.Inf. H. Tjutjup Suparna dari tahun 1991 hingga Juni 2001 (Pemkot Balikpapan, 2018), yang dikenal dengan slogan kota Beriman (Bersih, Indah, Aman, dan Nyaman) yang diterjemahkan oleh Pak Tjutjup sebagai Beriman Fisiknya, Beriman Warganya kepada Tuhan Yang Maha Esa, Beriman Berprestasi Inovasi dan Mandiri. Kemudian dilanjutkan oleh $\mathrm{H}$. Imdaad Hamid yang memimpin Kota Balikpapan pada era tahun 2001 hingga tahun 2011 (Pemkot Balikapapan, 2018) yang terkenal dengan slogan kota Kubangun, Kujaga, dan Kubela, yang dikenal hingga sekarang oleh seluruh masyarakat Kota Balikpapan. Dan yang teranyar adalah Walikota Rizal Effendi yang memimpin kota Balikpapan setelah menggantikan Imdaad Hamid sejak 2011 hingga sekarang (Pemkot Balikpapan, 2018).

Yang unik dari pola kepemimpinan Kota Balikpapan dari waktu ke waktu, sejak tahun 1980an tersebut adalah penerus pucuk pimpinan Walikota Balikpapan memiliki latar belakang yang sama dengan Walikota sebelumnya atau berasal dari dalam pemerintahanan Kota Balikpapan itu sendiri. Yang artinya, penerus Walikota Balikpapan telah mengetahui seluk beluk permasalahan dan visi misi Kota Balikpapan.

Pola komitmen yang konsisten tersebut juga menunjukkan bahwa Pemerintah Kota Balikpapan memahami dan telah lama menanamkan pemahaman kepada masyarakat Kota Balikpapan tentang arti pentingnya menjaga lingkungan hidup Kota Balikpapan, yang diwujudkan dengan capaian Adipura Kencana 2017 dan juga Adipura-Adipura Kencana sebelumnya.

Keunggulan Keempat yang juga dimiliki Pemerintah Kota Balikpapan, sebagaimana disampaikan oleh Bapak Suryanto dan $\mathrm{Bu}$ Ririn, sebagai usaha mewujudkan pemahaman masyarakat Balikpapan yang cinta lingkungan, adalah dengan penerapan Muatan Lokal tentang materi Lingkungan Hidup yang mulai diterapkan diseluruh instansi pendidikan dasar hingga tingkat atas di Kota Balikpapan yang dimulai sejak tahun 2009 pada era Walikota Imdaad Hamid, dan masih berjalan hingga sekarang.

Pemerintah Kota Balikpapan telah secara aktif mengkomunikasikan program pemerintah yang sedang berjalan kepada seluruh pemangku kepentingan, baik internal maupun eksternal keorganisasian Pemerintah Kota Balikpapan, sebagaimana West dan Turner (2010) menyatakan bahwa komunikasi organisasi mencakup komunikasi yang terjadi di dalam dan di antara lingkungan kerja, dimana pada kasus ini Pemerintah Kota Balikpapan berkomunikasi secara keorganisasian di dalam lingkup pemerintahan, antar dinas dan di dalam dinas yang bernaung di bawah struktur eksekutif 
Pemerintah Kota Balikpapan, selain juga berkomunikasi secara aktif dengan pemangku kepentingan di luar lingkup pemerintahan, seperti masyarakat umum dan korporasi di wilayah Balikpapan.

Komunikasi organisasi Pemerintah Kota Balikpapan ini sesuai juga dengan definisi dari komunikasi organisasi dari Prayudi pada Rochmah (2012), dimana Pemerintah Kota Balikpapan, membentuk infrastruktur profesional untuk mengembangkan dan mendistribusikan informasi terkait program pemerintah, salah satunya program Adipura dan pengelolaan lingkungan hidup secara umum melalui cara yang dapat dipercaya (dimana memiliki landasan hukum) dan tidak lekang waktu (dijalankan secara profesional dan berkesinambungan), yaitu adanya Dinas Lingkungan Hidup dan diterbitkannya berbagai peraturan daerah maupun peraturan walikota lainnya berikut dengan perangkat hukumnya, seperti:

1. Peraturan Daerah Kota Balikpapan No. 12 tahun 2012 tentang Rencana Tata Ruang Wilayah Kota Balikpapan tahun 2012-2032.

2. Peraturan Walikota Kota Balikpapan No. 56 tahun 2016 tentang Susunan Organisasi, Uraian Tugas dan Fungsi Dinas Lingkungan Hidup. Tanpa adanya Dinas Lingkungan Hidup di Kota Balikpapan

3. Peraturan Daerah Kota Balikpapan No. 13 tahun 2015 tentang Pengelolaan Sampah Rumah Tangga dan Sampah Sejenis Sampah Rumah Tangga

4. Dokumen Indikator Kinerja Pengelolaan Lingkungan Hidup Daerah (DIKPLHD) Kota Balikpapan tahun 2016, dan lain-lain.

Juga didalamnya sesuai dengan definisi komunikasi organisasi dari West dan Turner (2010) dimana Pemerintah Kota Balikpapan membangun komunikasi interpersonal (antara atasan dan bawahan), yaitu antara Walikota dan jajaran pemerintahan hingga tingkat Lurah di dalam forum Coffee Morning, antara Kepala Dinas Lingkungan Hidup dengan seluruh staf dibawahnya seperti Bidang Kebersihan dan Bidang Penataan Hukum dan Peningkatan Kapasitas Lingkungan Hidup dan bidang-bidang lainnya, dan antara Kepala Bidang Kebersihan dengan petugas kebersihan, kesempatan berbicara di depan publik dan kelompok kecil seperti dalam sambutan-sambutan Walikota, Kepala dan seluruh staf Dinas Lingkungan Hidup dalam forum yang resmi maupun tidak resmi (informal) seperti arisan, PKK, dasawisma, pengajian, dan lain-lain, dan komunikasi dengan menggunakan media, dimana Pemerintah Kota Balikpapan memanfaatkan berbagai media yang ada, yaitu media internal Pemerintah Kota melalui Dinas Komunikasi dan Informasi (kominfo) dan Dinas Lingkungan Hidup, radio, TV, media cetak, dan juga media sosial seperti facebook dan instagram untuk mengkomunikasikan program pemerintah, salah satunya adalah Adipura.

Berdasarkan hasil wawancara dengan narasumber terkait, bahwa Pemerintah Kota Balikpapan dalam mengkomunikasikan program-programnya, salah satunya Adipura, melalui agenda formal seperti Coffee Morning atau rapat resmi pemerintahan/antar dinas, pidato walikota, dan lain-lain ataupun informal ketika pegawai termasuk kepala Dinas Lingkungan Hidup Kota Balikpapan berkunjung menghadiri undangan dari masyarakat Kota Balikpapan dan menggunakan kesempatan tersebut untuk menyampaikan program Adipura. Media komunikasi yang digunakanpun juga beragam yaitu penggunaan website resmi Pemerintah Kota Balikpapan, media massa, radio, facebook, instragram, dan lain sebagainya.

Temuan ini selaras dengan definisi dari Rochmah (2012) yang menambahkan bahwa strategi komunikasi merupakan kegiatan komunikasi yang sifatnya informasional maupun persuasif yang ditunjukkan adanya proses komunikasi antara Pemerintah Kota Balikpapan dengan publiknya untuk membangun pemahaman dan dukungan masyarakat atas program Adipura, yang direncanakan dan dilakukan oleh Pemerintah Kota Balikpapan berdasarkan riset dan evaluasi atas capaian tahun-tahun sebelumnya maupun temuan pada saat peninjauan tahap awal demi mencapai Kota Balikpapan yang berwawasan lingkungan dan menuju pembangunan yang berkelanjutan, yang dibuktikan dengan raihan Adipura Kencana 2017.

Dalam kontek pendekatan strategi komunikasi yang digunakan, Pemerintah Kota Balikpapan lebih banyak mengedepankan strategi komunikasi yang proakif, dimana inovasi/inisiatif program didasarkan pada rencana dan kondisi dari Pemerintah Kota Balikpapan sendiri. Kepala Dinas Lingkungan Hidup Kota Balikpapan, Bapak Suryanto menyatakan dalam wawancara tanggal 11 Juli 2018 bahwa capaian prestasi Kota Balikpapan dalam penghargaan Adipura tidak dicapai dengan cara instan, tetapi melalui proses komunikasi yang panjang, yang dijalankan secara terus menerus dan sudah berlangsung lama. Faktor kepemimpinan dan komitmen kepala daerah memegang peranan penting dalam pencapaian penghargaan ini. Diutarakan dalam wawancara tanggal 11 Juli 2018, Bapak Suryanto menyatakan bahwa setiap awal minggu Walikota dan seluruh Organisasi Perangkat Daerah mulai dari Kepala Dinas hingga Lurah mengadakan rapat koordinasi rutin "Coffee Morning" yang ditujukan untuk mengkomunikasikan dan mendiskusikan isu-isu tentang Kota Balikpapan yang sedang hangat dan perlu mendapatkan perhatian segera dari Pemerintah Kota Balikpapan. Pada saat meeting ini, seluruh temuan, keluhan atas pelayanan Dinas terkait, dan juga agenda penting disampaikan dan didiskusikan bersama, agar seluruh pihak memahami peran dan tugasnya masingmasing. Keterbukaan antar Dinas/Instansi juga menjadi kunci keefektifan program ini.

Termasuk juga didiskusikan dalam Coffee Morning adalah program Adipura. Dinas Lingkungan Hidup yang diwakili Kepala Dinasnya menyampaikan agenda-agenda penting, temuan pada penilaian sebelumnya, dan lain- 
lain kepada seluruh peserta Coffee Morning sehingga dinas-dinas terkait dapat menyampaikan informasi yang diterima kepada anggota yang berada di bawah naungannya.

Strategi komunikasi proaktif yang juga telah berjalan sejak lama adalah program pelajaran Muatan Lokal tentang Lingkungan Hidup di seluruh instansi pendidikan formal yang ada di Balikpapan, mulai tingkat dasar hingga tingkat atas, dan berjalan hingga sekarang. Dengan mengajarkan sejak dini kecintaan terhadap lingkungan, Pemerintah Kota Balikpapan yakin hal tersebut dapat meningkatkan kesadaran masyarakat (sebagai hasil pemahaman akan pentingnya menjaga lingkungan, penerimaan akan nilai positif atas apa yang disampaikan oleh Pemerintahnya) Kota Balikpapan sehingga mampu memotivasi masyarakat untuk turut andil dalam menjaga lingkungan hidup mereka dan pada akhirnya Kota Balikpapan menjadi kota yang nyaman dan layak untuk dihuni, dan dengan sendirinya Pemerintah Kota Balikpapan dan seluruh pemangku kepentingan didalamnya dapat mewujudkan Kota Balikpapan yang layak huni sesuai dengan visi misi Kota Balikpapan. Namun demikian, strategi komunikasi Pemerintah Kota Balikpapan juga bersifat reaktif yang salah satunya dibuktikan dengan pemberian bonus ketika Adipura Kencana telah diraih yang diberikan kepada pasukan kuning/petugas kebersihan Kota Balikpapan.

Dalam menjalankan strategi komunikasi tersebut, Pemerintah Kota Balikpapan menggunakan berbagai taktik diantaranya dengan menggunakan komunikasi interpersonal antar Walikota Balikpapan dengan dinas dalam lingkup Pemerintah Kota Balikpapan, antar dinas terkait, di dalam lingkup dinas, maupun antara Pemerintah dengan masyarakat umum, yang dimanfaatkan untuk mendapatkan personal touch maupun interaksi antar pribadi (Smith, 2013) yang pada akhirnya memberikan efek persuasif yang paling besar (Smith, 2013) yang ditunjukkan dengan besarnya dampak pada Coffee Morning maupun komunikasi sejenis seperti yang dilakukan oleh Kepala Dinas Lingkungan Hidup Bapak Suryanto dalam memberikan motivasi kepada bawahannya. Pemanfaatan media internal Pemerintah Kota Balikpapan juga dimanfaatkan dengan baik, demikian juga penggunaan media massa maupun media social seiring dengan meningkatnya penggunaan media internet dalam kemudahan penyebaran informasi pada era globalisasi seperti saat ini.

Berbagai program pendekatan komunikasi yang dijalankan Pemerintah Kota Balikpapan dalam berkomunikasi dengan massanya (yaitu masyarakat Kota Balikpapan) yang dijalankan dalam kurun waktu yang lama dan berkesinambungan, terus-menerus merupakan bentuk dari persuasi Pemerintah Kota Balikpapan yang sesuai dengan definisi persuasi menurut Littlejohn dan Foss (2009) dimana didalamnya terdapat aktivitas menciptakan, menguatkan, atau merubah kepercayaan, tindakan, dan perilaku orang, dalam hal ini adalah masyarakat atau publik umum dan juga jajaran pegawai pemerintahan Kota Balikpapan, sebagaimana apa yang disampaikan oleh Edgett, Curtin dan Gaither, Pfau dan Wan, Byrne, James, dan Porter pada Harrison (2011) tentang persuasi yang merupakan inti dalam setiap kegiatan public relations, dimana public relations adalah propaganda (Harrison, 2011).

Lebih lanjut sebagaimana definisi Littlejohn dan Foss (2009) tentang propaganda bahwa propaganda merupakan bagian dari persuasi, dimana didalamnya terdapat usaha sungguh-sungguh yang berusaha untuk mengubah atau mempengaruhi perilaku dari target sasarannya, dalam hal ini adalah masyarakat Kota Balikpapan. Pemerintah Kota Balikpapan dengan sungguh-sungguh menjalankan usahanya untuk mengubah atau mempengaruhi perilaku dan mendapatkan kepercayaan dari masyarakat Kota Balikpapan khususnya dalam meningkatkan kesadaran dan partisipasi aktif masyarakat Kota Balikpapan dalam menjaga lingkungan dan kebersihan Kota Balikpapan, sebagaimana salah satu contohnya adalah dengan dikeluarkannya Dokumen Indikator Kinerja Pengelolaan Lingkungan Hidup Daerah (DIKPLHD) pada tahun 2016 yang mana sebagai hadiahnya adalah prestasi Adipura Kencana 2017.

Secara keseluruhan tujuan proses pelaksanaan strategi komunikasi Pemerintah Kota Balikpapan dalam meraih penghargaan Adipura Kencana 2017 yang lalu dapat dicapai dengan memenuhi tujuan-tujuan dilaksanakannya strategi komunikasi sesuai dengan teori Strategi Komunikas menurut Pace, Peterson, dan Burnett pada Effendy (2009) dan Pace dan Faules pada Rochmah (2012). Sedangkan penyampaian komunikasi yang dimaksud, kepada internal dan eksternal, dilakukan dengan menggunakan persuasi massa/propaganda dengan memanfaatkan media yang ada (internal dan eksternal).

\section{KESIMPULAN}

Strategi komunikasi Pemerintah Kota Balikpapan dilakukan dengan pendekatan proaktif yang telah dilakukan secara berkesinambungan oleh pemimpinpemimpin Kota Balikpapan terdahulu hingga sekarang dengan publikasi/publisitas, menjadikan topik lingkungan hidup seperti Adipura memiliki nilai berita, dan membangun proses komunikasi yang transparan.

Di dalam menjalankan strategi komunikasi tersebut, taktik komunikasi yang digunakan oleh Pemerintah Kota Balikpapan adalah dengan berkomunikasi interpersonal dalam lingkup internal dan juga eksternal dan juga dengan memanfaatkan media internal maupun media eksternal dan dilakukan secara persuasi atau propaganda kepada masyarakat Kota Balikpapan dan telah berlangsung lama dan berjalan secara berkesinambungan. 


\section{SARAN}

Untuk menambah kajian pada penelitian selanjutnya, disarankan penelitian serupa dapat dilakukan dengan metode kuantitatif dengan teori komunikasi lainnya untuk mengukur motivasi masyarakat dalam mendukung pemerintahnya dalam program Adipura atau mengukur pengaruh strategi komunikasi pemerintah terhadap pencapaian penghargaan Adipura.

\section{DAFTAR PUSTAKA}

Ary, D., Jacobs, L.C., Sorensen, C.K. \& Razavieh, A. 2010. Introduction to Research in Education, $8^{\text {th }}$ ed, Belmont, Wadsworh Cengage Learning.

Creswell, J.W. 2016, Research Design: Pendekatan Metode Kualitatif, Kuantitatif, dan Campuran, $4^{\text {th }}$ ed, Yogjakarta, Pustaka Pelajar.

Denzin, N.K., \& Lincoln, Y.S. 2009, Hand Book of Qualitative Research, Yogjakarta, Pustaka Pelajar.

Dinas Komunikasi dan Informasi Balikpapan (Diskominfo Balikpapan). 2017, Balikpapan Kembali Raih Adipura Kencana, Narwasita Tantra, Kalpataru, dan Adiwiyata Mandiri. Diperoleh dari http://balikpapan.go.id/berita/detail/7385/balikpapa n-kembali-raih-adipura-kencana-nirwasita-tantrakalpataru-dan-adiwiyata-mandiri.

Dinas Lingkungan Hidup Samarinda. 2017, Daftar Kota Peraih Adipura 2017, Diperoleh dari http://dlh.samarindakota.go.id/regulasi/keputusanwalikota/item/172-daftar-kota-peraih-adipura-2017

Effendy, O.U. 2009, Ilmu Komunikasi: Teori dan Praktek, Bandung, Remaja Rosdakarya.

Gregory, A. 2010, Planning and Managing Public Relations Campaigns: A Strategic Approach, $3^{\text {rd }}$ ed, London, Kogan Page Ltd.

Harrison, K. 2011, Strategic Public Relations: A Practical Guide to Success, South Yarra, Palgrave Mcmillan.

Kementerian Lingkungan Hidup dan Kehutanan (KLHK). 2016, Pedoman Pelaksanaan Adipura 2016, Diperoleh dari http://www.bandungkab.go.id/uploads/PERMENL HK\%20NO\%2053\%20TAHUN\%202016\%20TTG

\section{\%20PEDOMAN\%20PELAKSANAAN\%20PROG}

RAM\%20ADIPURA.pdf.

Littlejohn, S.W., \& Foss, K.A. 2009, Encyclopedia of Communication Theory, New York, Sage Publications.

Miles, M.B., Huberman, A.M., \& Saldana, J. 2014, Qualitative Data Analysis : A Methods Sourcebook, $3^{\text {rd }}$ ed, California, Sage Publications.

Moleong, L.J. 2010, Metodologi Penelitian Kualitatif, Bandung, Remaja Rosdakarya.

Pemkot Balikpapan. 2018, Penghargaan. Diperoleh dari http://balikpapan.go.id/read/1001/penghargaan pada 11 Agustus 2018.

Pemkot Balikpapan. 2018, Selayang Pandang. Diperoleh dari http://balikpapan.go.id/read/98/selayangpandang pada 11 Agustus 2018.

Pemkot Balikpapan. 2018, Sejarah - Walikota dari Masa ke Masa. Diperoleh dari http://balikpapan.go.id/read/46/sejarah pada 11 Agustus 2018.

Rochmah, N.J. 2012. Analisis Strategi Komunikasi External Lembaga Penyiaran Publik untuk Menguatkan Reputasi di Mata Masyarakat : Studi Deskriptif Kualitatif pada Radio Republik Indonesia (Master thesis), Jakarta, Univesitas Indonesia.

Samsuriyadi. 2017, Strategi Pemerintah Kota Bintan dalam Meraih Penghargaan Adipura tahun 2015. (Undergraduate Thesis, Universitas Maritim Raja Ali Haji, Tanjung Pinang), Diperoleh dari http://jurnal.umrah.ac.id/wpcontent/uploads/gravity_forms/1ec61c9cb232a03a96d0947c6478e525e/2017/02/EJurnal.pdf.

Septiana, I. 2016, Evaluasi Strategi Pemerintah Kota Pekanbaru Dalam Mempertahankan Adipura tahun 2014-2015, Jom Fisip 3(2):1 - 14.

Smith, R.D. 2013, Strategic Planning for Public Relations, $4^{\text {th }}$ ed, New York, Routledge.

West, R., \& Turner, L,H, 2010, Introducing Communication Theory: Analysis dan Aplication, $4^{\text {th }}$ ed, New York, McGraw-Hill. 